\author{
Zh.N. Tasmambetov, A.A. Issenova
}

K. Zhubanov Aktobe regional state university, Kazakhstan (E-mail: tasmam@rambler.ru, akkenje_ia@mail.ru)

\title{
Bessel functions of two variables as solutions for systems of the second order differential equations
}

\begin{abstract}
In this paper, the systems with solutions in the form of degenerate hypergeometric Humbert functions of two variables reduced to Bessel functions of two variables are established and studied. The connections between the Humbert and Bessel functions of two variables are revealed, their differential properties are investigated. The addition and multiplication theorems are proved. In future, these proven properties allow us to establish recurrent relations between degenerate hypergeometric functions of two variables, similarly to extend these properties to the case of many variables. The connection between type systems of Bessel and Whittaker is shown. Using the Frobenius-Latysheva method, the singularities of constructing normalregular solutions of the newly established Bessel-type system are studied.
\end{abstract}

Keywords: Humbert function, system, Bessel function, properties, addition theorem, reducible, normalregular.

\section{Introduction}

Applications of Bessel functions of one variable are very diverse. They are widely used in solving problems of acoustics, Radiophysics, hydrodynamics, nuclear and nuclear physics. In the theory of elasticity the solution in Bessel functions covers all spatial problems solved in spherical and cylindrical coordinates, various problems of vibrations of plates. There are also numerous publications, which study a large number of different problems relating to all important sections of mathematical physics. However, this work out has not received the development of the theory of Bessel functions of many variables. Although there are works where the properties of Bessel functions of many variables are studied, their relation to various special functions and orthogonal polynomials of many variables is analogous to the Bessel function of one variable. It is a special case of the degenerate hypergeometric Kummer function $[1 ; 1]$. It is known that the particular solution of the Kummer equation is a degenerate Gauss function $G(\alpha, \gamma ; x)$ :

$$
\lim _{\tau \rightarrow 0} F\left(\alpha, \frac{1}{\varepsilon} ; \gamma ; \varepsilon x\right)=\sum_{m=0}^{\infty} \frac{(\alpha)_{m}}{(\gamma)_{m}} \cdot \frac{x^{m}}{m !}=G(\alpha, \gamma ; x)
$$

obtained by the limit transition. Similarly, you can get the function

$$
\lim _{\tau \rightarrow 0} F\left(\frac{1}{\varepsilon}, \frac{1}{\varepsilon} ; \gamma ; \varepsilon^{2} x\right)=\sum_{m=0}^{\infty} \frac{1}{(\gamma)_{m}} \cdot \frac{x^{m}}{m !}=J(\gamma ; x)
$$

$J(\gamma ; x)$ is called the function reduced to the Bessel function, since equality is just

$$
J_{k}(x)=\frac{\left(\frac{x}{2}\right)^{k}}{\Gamma(k+1)} \cdot J\left(k+1,-\frac{x^{2}}{2}\right)
$$

and

$$
x^{2} \frac{d^{2} J_{k}}{d x^{2}}+x \frac{d J_{k}}{d x}+\left(x^{2}-k^{2}\right) J_{k}=0
$$

where (1.4) is the basic Bessel equation. 
All known hypergeometric functions of two variables are solutions of some special systems consisting of two partial differential equations of the second order. In Horn list there are 34 such systems whose solutions are 34 hypergeometric functions of two variables. Out of them 20 are degenerate hypergeometric functions of two variables [2,3]. The connection of Bessel functions of two variables with these degenerate functions of two variables is not studied properly. In several works [4; 138] it was proven that a function of M.P. Humbert $\Psi_{2}\left(\alpha, \gamma, \gamma^{\prime} ; x, y\right)$ is the most closest to the Bessel functions [5; 129].

Definition 1.1. The degenerate hypergeometric Humbert function $\Psi_{2}\left(\alpha, \gamma, \gamma^{\prime} ; x, y\right)$ two variables $x$ and $y$ is determined by a series of

$$
\Psi_{2}\left(\alpha, \gamma, \gamma^{\prime} ; x_{1}, x_{2}\right)=\sum_{m, n=0}^{\infty} \frac{(\lambda)_{m+n}}{(\gamma)_{m}\left(\gamma^{\prime}\right)_{n}} \cdot \frac{x_{1}^{m}}{m !} \cdot \frac{x_{2}^{n}}{n !}
$$

The series (1.5) converges absolutely and uniformly if at $\left|x_{1}\right|<\varepsilon,\left|x_{2}\right|<\varepsilon$.

Theorem 1.1. Series (1.5) is a particular solution of the Horn system

$$
\left\{\begin{array}{l}
x_{1} Z_{x_{1} x_{1}}+\left(\gamma-x_{1}\right) Z_{x_{1}}-x_{2} Z_{x_{2}}-\lambda Z=0 \\
x_{2} Z_{x_{2} x_{2}}+\left(\gamma^{\prime}-x_{2}\right) Z_{x_{2}}-x_{1} Z_{x_{1}}-\lambda Z=0
\end{array}\right.
$$

which under the conditions of compatibility and integrability has four linearly independent partial solutions [6].

In the monograph of Appell and Kampe de Feriet [5; 124] there is a list of 23 (I-XXIII) degenerate hypergeometric functions of two variables derived from four Appell functions $F_{1}-F_{4}$ given by limit transition. Some of them coincide, despite the fact that they are obtained from various hypergeometric functions of Appell $F_{1}-F_{4}$. Five functions of them: (XIII), (XVI), (XVII), (XVIII) and (XXIII) are presented as a product of the function, which is reduced to the Bessel functions or functions of Bessel and Kummer.

Example 1. A number of (XVI)

$$
\begin{gathered}
\lim _{\tau \rightarrow 0} F_{2}\left(\frac{1}{\varepsilon}, \frac{1}{\varepsilon}, \frac{1}{\varepsilon} ; \gamma_{1} ; \gamma_{2} ; \varepsilon^{2} x_{1}, \varepsilon^{2} x_{2}\right)= \\
=\sum_{m, n=0}^{\infty} \frac{1}{\left(\gamma_{1}\right)_{m}\left(\gamma_{2}\right)_{n}} \cdot \frac{x_{1}^{m}}{m !} \cdot \frac{x_{2}^{n}}{n !}=J\left(\gamma_{1} ; x_{1}\right) \cdot J\left(\gamma_{2} ; x_{2}\right)
\end{gathered}
$$

set by limit transition, where the functions $J\left(\gamma_{j} ; x_{j}\right),(j=1,2)$ of the reduced to Bessel functions are a particular solution of the system

$$
\left\{\begin{array}{l}
x_{1} Z_{x_{1} x_{1}}+\gamma_{1} Z_{x_{1}}-Z=0 \\
x_{2} Z_{x_{2} x_{2}}+\gamma_{2} Z_{x_{2}}-Z=0
\end{array}\right.
$$

obtained by limiting the transition from the Horn system $\left(F_{2}\right)$.

The aim of this work is to establish and study systems with solutions in the form Bessel functions of two variables, using the Horn systems (1.6), to establish the connection of Bessel functions to the Humbert function and with other functions from the Horn list, to investigate their differential properties, addition and multiplication theorems, based on the properties of the Humbert function.

2. Properties of degenerate hypergeometric series reducible to Bessel functions of two variables.

In the previous paragraph we defined Kummer function (1.1), as the degenerated Gaussian function. A function reducible to the Bessel function of one variable [7;21] was defined using the limit transition (1.2). Similarly, the limit transition is just

$$
F_{1}(; \gamma ; x)=1+\frac{1}{\gamma} x+\frac{1}{2 ! \gamma(\gamma+1)} x^{2}+\cdots=
$$




$$
=\lim _{\alpha \rightarrow \infty}\left[1+\frac{\alpha}{1 ! \gamma} \frac{x}{\alpha}+\frac{\alpha(\alpha+1)}{2 ! \gamma(\gamma+1)} \frac{x^{2}}{\alpha^{2}}+\cdots\right]=J(\gamma ; x)
$$

We are interested in generalizing (2.1) in the case of a degenerate hypergeometric function of two variables.

Theorem 2.1. The degenerated hypergeometric Humbert function $\Psi_{2}\left(\lambda ; \gamma_{1}, \gamma_{2} ; x_{1}, x_{2}\right)$ of two variables by means of a limit transition is reduced to the form

$$
\lim _{\lambda \rightarrow \infty}=\Psi_{2}\left(\lambda ; \gamma_{1}, \gamma_{2} ; x_{1}, x_{2}\right)=J\left(\gamma_{1} ; x_{1}\right) J\left(\gamma_{2} ; x_{2}\right)
$$

where functions $J\left(\gamma_{j} ; x_{j}\right),(j=1,2)$ are reduced to Bessel functions.

Proof. Indeed, there is the limit of a function of Humbert when $\lambda \rightarrow \infty$

$$
\begin{gathered}
\lim _{\lambda \rightarrow \infty} \Psi_{2}\left(\lambda ; \gamma_{1}, \gamma_{2} ; \frac{x_{1}}{\lambda}, \frac{x_{2}}{\lambda}\right)=\lim _{\lambda \rightarrow \infty}\left[1+\frac{\lambda}{1 ! \gamma_{1}} \frac{x_{1}}{\lambda}+\frac{\lambda}{1 ! \gamma_{2}} \frac{x_{2}}{\lambda}+\frac{\lambda(\lambda+1)}{1 ! \gamma_{1} \gamma_{2}} \frac{x_{1}}{\lambda} \frac{x_{2}}{\lambda}+\right. \\
\left.+\frac{\lambda(\lambda+1)}{2 ! \gamma_{1}\left(\gamma_{1}+1\right)} \frac{x_{1}^{2}}{\lambda^{2}}+\frac{\lambda(\lambda+1)}{2 ! \gamma_{2}\left(\gamma_{2}+1\right)} \frac{x_{2}^{2}}{\lambda^{2}}+\cdots\right]=1+\frac{1}{1 ! \gamma_{1}} x_{1}+\frac{1}{1 ! \gamma_{2}} x_{2}+\frac{1}{1 ! \gamma_{1} \gamma_{2}} x_{1} x_{2}+ \\
+\frac{1}{2 ! \gamma_{1}\left(\gamma_{1}+1\right)} x_{1}^{2}+\frac{1}{2 ! \gamma_{2}\left(\gamma_{2}+1\right)} x_{2}^{2}+\cdots=\left(1+\frac{1}{1 ! \gamma_{1}} x_{1}+\frac{1}{2 ! \gamma_{1}\left(\gamma_{1}+1\right)} x_{1}^{2}+\cdots\right) . \\
\cdot\left(1+\frac{1}{1 ! \gamma_{2}} x_{2}+\frac{1}{2 ! \gamma_{2}\left(\gamma_{2}+1\right)} x_{2}^{2}+\cdots\right)=J\left(\gamma_{1} ; x_{1}\right) J\left(\gamma_{2} ; x_{2}\right)=J\left(\gamma_{1}, \gamma_{2} ; x_{1}, x_{2}\right) .
\end{gathered}
$$

Taking into account (2.1) and (2.2) we obtain a series of two variables

$$
J\left(\gamma_{1} ; x_{1}\right) J\left(\gamma_{2} ; x_{2}\right)=\sum_{m_{1}, m_{2}=0}^{\infty} \frac{1}{\left(\gamma_{1}\right)_{m_{1}}\left(\gamma_{2}\right)_{m_{2}}} \cdot \frac{x_{1}^{m_{1}}}{m_{1} !} \cdot \frac{x_{2}^{m_{2}}}{m_{2} !} .
$$

Theorem 2.2. The Bessel function of two variables of the first kind is represented as

$$
J_{\gamma_{1}, \gamma_{2}}\left(x_{1}, x_{2}\right)=\sum_{m_{1}, m_{2}=0}^{\infty} \frac{(-1)^{m_{1}+m_{2}}}{m_{1} ! \cdot m_{2} ! \Gamma\left(\gamma_{1}+m_{1}+1\right) \Gamma\left(\gamma_{2}+m_{2}+1\right)} \cdot\left(\frac{x_{1}}{2}\right)^{2 m_{1}+\gamma_{1}} \cdot\left(\frac{x_{2}}{2}\right)^{2 m_{2}+\gamma_{2}}
$$

Indeed, using (1.3) and the obtained functions by the limiting transition (2.3) and the series (1.7) we have

$$
\begin{gathered}
J_{\gamma_{1}, \gamma_{2}}\left(x_{1}, x_{2}\right)=\frac{\left(\frac{x_{1}}{2}\right)^{\gamma_{1}}}{\Gamma\left(\gamma_{1}+1\right)} \cdot \frac{\left(\frac{x_{2}}{2}\right)^{\gamma_{2}}}{\Gamma\left(\gamma_{2}+1\right)} \cdot J_{\gamma_{1}}\left(\gamma_{1}+1 ;-\frac{x_{1}^{2}}{2^{2}}\right) J_{\gamma_{2}}\left(\gamma_{2}+1 ;-\frac{x_{2}^{2}}{2^{2}}\right)= \\
=\frac{\left(\frac{x_{1}}{2}\right)^{\gamma_{1}}}{\Gamma\left(\gamma_{1}+1\right)} \cdot \frac{\left(\frac{x_{2}}{2}\right)^{\gamma_{2}}}{\Gamma\left(\gamma_{2}+1\right)} \cdot J\left(\gamma_{1}+1, \gamma_{2}+1 ;-\frac{x_{1}^{2}}{2^{2}},-\frac{x_{2}^{2}}{2^{2}}\right)= \\
=\frac{\left(\frac{x_{1}}{2}\right)^{\gamma_{1}}}{\Gamma\left(\gamma_{1}+1\right)} \cdot \frac{\left(\frac{x_{2}}{2}\right)^{\gamma_{2}}}{\Gamma\left(\gamma_{2}+1\right)} \cdot\left[1-\frac{1}{1 !\left(\gamma_{1}+1\right)} \cdot \frac{x_{1}^{2}}{2^{2}}-\frac{1}{1 !\left(\gamma_{2}+1\right)} \cdot \frac{x_{2}^{2}}{2^{2}}+\frac{1}{2 !\left(\gamma_{1}+1\right)\left(\gamma_{1}+2\right)} \cdot\left(\frac{x_{1}^{2}}{2^{2}}\right)^{2}+\right. \\
\left.+\frac{1}{1 !\left(\gamma_{1}+1\right)\left(\gamma_{2}+1\right)} \cdot\left(\frac{x_{1}^{2}}{2^{2}}\right) \cdot\left(\frac{x_{2}^{2}}{2^{2}}\right)+\frac{1}{2 !\left(\gamma_{2}+1\right)\left(\gamma_{2}+2\right)} \cdot\left(\frac{x_{2}^{2}}{2^{2}}\right)^{2}+\cdots\right]= \\
=\frac{\left(\frac{x_{1}}{2}\right)^{\gamma_{1}}}{\Gamma\left(\gamma_{1}+1\right)} \cdot \frac{\left(\frac{x_{2}}{2}\right)^{\gamma_{2}}}{\Gamma\left(\gamma_{2}+1\right)} \sum_{m_{1}, m_{2}=0}^{\infty} \frac{(-1)^{m_{1}+m_{2}}\left(\frac{x_{1}}{2}\right)^{2 m_{1}} \cdot\left(\frac{x_{2}}{2}\right)^{2 m_{2}}}{m_{1} ! \cdot m_{2} ! \Gamma\left(m_{1}+1\right) \Gamma\left(m_{2}+1\right)}= \\
=\sum_{m_{1}, m_{2}=0}^{\infty} \frac{(-1)^{m_{1}+m_{2}}}{m_{1} ! \cdot m_{2} ! \Gamma\left(\gamma_{1}+m_{1}+1\right) \Gamma\left(\gamma_{2}+m_{2}+1\right)} \cdot\left(\frac{x_{1}}{2}\right)^{2 m_{1}+\gamma_{1}} \cdot\left(\frac{x_{2}}{2}\right)^{2 m_{2}+\gamma_{2}} .
\end{gathered}
$$


(2.6) shows the rightly of presentation (2.5).

Solutions of the system (1.8) are not difficult to build [8;203].

Theorem 2.3. The system of differential equations (1.8) has four linearly independent partial solutions in the form of series, which are reduced to Bessel functions,

$$
\begin{gathered}
Z_{1}\left(x_{1}, x_{2}\right)=J\left(\gamma_{1} ; x_{1}\right) J\left(\gamma_{2} ; x_{2}\right)=\sum_{m, n=0}^{\infty} \frac{1}{\left(\gamma_{1}\right)_{m}\left(\gamma_{2}\right)_{n}} \cdot \frac{x_{1}^{m}}{m !} \cdot \frac{x_{2}^{n}}{n !}, \\
Z_{2}\left(x_{1}, x_{2}\right)=x_{2}^{1-\gamma_{2}} J\left(\gamma_{1} ; x_{1}\right) J\left(2-\gamma_{2} ; x_{2}\right) \\
Z_{3}\left(x_{1}, x_{2}\right)=x_{1}^{1-\gamma_{1}} J\left(2-\gamma_{1} ; x_{1}\right) J\left(\gamma_{2} ; x_{2}\right), \\
Z_{4}\left(x_{1}, x_{2}\right)=x_{1}^{1-\gamma_{1}} \cdot x^{1-\gamma_{2}} J\left(2-\gamma_{1} ; x_{1}\right) J\left(2-\gamma_{2} ; x_{2}\right)
\end{gathered}
$$

Proof. Near the singularity $(0,0)$ we look for a solution in the form of a generalized power series of two variables

$$
Z=x^{\rho} y^{\sigma} \sum_{m, n=0}^{\infty} A_{m, n} \cdot x^{m} \cdot y^{n},\left(A_{0,0} \neq 0\right)
$$

where $\rho, \sigma, A_{m, n}(m, n=0,1,2, \ldots)$ are unknown constants.

In (2.8) unknown constants $\rho$ and $\sigma$ are determined from a system of defining equations regarding features $(0,0)$. It has four pairs of roots: $(0,0),\left(0,1-\gamma_{2}\right),\left(1-\gamma_{1}, 0\right),\left(1-\gamma_{1}, 1-\gamma_{2}\right)$.

Unknown coefficients $A_{m, n}(m, n=0,1,2, \ldots)$ are determined from the system of recurrent sequences,

$$
\sum_{m, n=0}^{\infty} A_{\mu-m, \nu-n}^{(j)} \cdot f_{m, n}^{(j)}(\rho+\mu-m, \sigma+\nu-n)=0
$$

$(\mu, \nu=0,1,2 \ldots ; j=1,2, \ldots)$. Then, given $(2.9)$ the values of the unknown constants, we obtain partial solutions of the form $\left(2.7_{t}\right)(t=\overline{1,4})$, where the first particular solution coincides with (2.4).

Various Appell $F_{1}-F_{4}$ functions are used to obtain series of the form (1.7).

Theorem 2.4. Row (XIII)

$$
\lim _{\tau \rightarrow 0} F_{2}\left(\frac{1}{\varepsilon}, \frac{1}{\varepsilon}, \frac{1}{\varepsilon} ; \gamma_{1} ; \gamma_{2} ; \varepsilon^{2} x_{1}, \varepsilon^{2} x_{2}\right)=\sum_{m, n=0}^{\infty} \frac{1}{(\gamma)_{m+n}} \cdot \frac{x_{1}^{m}}{m !} \cdot \frac{x_{2}^{n}}{n !}=J\left(\gamma ; x_{1}+x_{2}\right),
$$

where the degenerate hypergeometric function $J\left(\gamma ; x_{1}+x_{2}\right)$ reduced to the Bessel function of two variables is a particular solution of the system

$$
\left\{\begin{array}{l}
x_{1} Z_{x_{1} x_{1}}+x_{2} Z_{x_{1} x_{2}}+\gamma_{1} Z_{x_{1}}-Z=0 \\
x_{2} Z_{x_{2} x_{2}}+x_{1} Z_{x_{1} x_{2}}+\gamma_{2} Z_{x_{2}}-Z=0
\end{array}\right.
$$

where $Z=Z\left(x_{1}, x_{2}\right)$ is the total unknown obtained by the limiting transition from the system

$$
\left\{\begin{array}{l}
x_{1}\left(1-\varepsilon^{2} x_{1}\right) Z_{x_{1} x_{1}}-x_{1}\left(1-\varepsilon^{2} x_{1}\right) Z_{x_{1} x_{2}}+\left[\gamma-\left(\frac{1}{\varepsilon}+\frac{1}{\varepsilon}+1\right) \varepsilon^{2} x_{1}\right] Z_{x_{1}}-\varepsilon x_{2} Z_{x_{2}}-Z=0 \\
x_{2}\left(1-\varepsilon^{2} x_{2}\right) Z_{x_{2} x_{2}}-x_{2}\left(1-\varepsilon^{2} x_{2}\right) Z_{x_{1} x_{2}}+\left[\gamma-\left(\frac{1}{\varepsilon}+\frac{1}{\varepsilon}+1\right) \varepsilon^{2} x_{2}\right] Z_{x_{2}}-\varepsilon x_{2} Z_{x_{1}}-Z=0 .
\end{array}\right.
$$

By the Frobenius-Latysheva method, we establish that the joint system (2.11) obtained by the limiting transition from the system (2.12) under the conditions of compatibility and

$$
1-\frac{x_{2}}{x_{1}} \cdot \frac{x_{1}}{x_{2}}=0
$$

has no more than three linearly independent solutions because (2.13) shows that the so-called integration condition fulfilled $[9 ; 85]$. 


\section{Main results}

\subsection{Differential properties of the Humbert and Bessel function}

The reasoning of the previous points shows that the Bessel function is mainly related to the Humbert function $\Psi_{2}\left(\lambda ; \gamma_{1}, \gamma_{2} ; x_{1}, x_{2}\right)$, which is a particular solution of the Horn system (1.6). Based on the General theory of such systems, as stated in theorem 1.1, the following statement is true.

Theorem 2.5. The Horn system has four linearly independent solutions:

$$
\begin{gathered}
Z_{1}=\sum_{m_{1}, m_{2}=0}^{\infty} \frac{(\lambda)_{m_{1}+m_{2}}}{\left(\gamma_{1}\right)_{m_{1}}\left(\gamma_{2}\right)_{m_{2}}} \cdot \frac{x_{1}^{m_{1}}}{m_{1} !} \cdot \frac{x_{2}^{m_{2}}}{m_{2} !}=\Psi_{2}\left(\lambda ; \gamma_{1}, \gamma_{2} ; x_{1}, x_{2}\right), \\
Z_{2}=x_{1}^{1-\gamma_{1}} \cdot \Psi_{2}\left(\lambda+1-\gamma_{1} ; 2-\gamma_{1}, \gamma_{2} ; x_{1}, x_{2}\right) \\
Z_{3}=x_{2}^{1-\gamma_{2}} \cdot \Psi_{2}\left(\lambda+1-\gamma_{2} ; \gamma_{1}, 2-\gamma_{2} ; x_{1}, x_{2}\right) \\
Z_{4}=x_{1}^{1-\gamma_{1}} \cdot x_{2}^{1-\gamma_{2}} \cdot \Psi_{2}\left(\lambda+2-\gamma_{1}-\gamma_{2} ; 2-\gamma_{1}, 2-\gamma_{2} ; x_{1}, x_{2}\right) .
\end{gathered}
$$

As can be seen here, the first particular solution (2.14) defines the Humbert function $\Psi_{2}$. We find the derivatives of this function.

Theorem 2.6. Derivatives of Humbert variables $x_{1}$ and $x_{2}$ presented in the form:

1 ) by variables $x_{1}$ and $x_{2}$;

$$
\left\{\begin{array}{l}
\frac{\partial}{\partial x_{1}} \Psi_{2}\left(\lambda ; \gamma_{1}, \gamma_{2} ; x_{1}, x_{2}\right)=\frac{\lambda}{\gamma_{1}} \Psi_{2}\left(\lambda+1 ; \gamma_{1}+1, \gamma_{2} ; x_{1}, x_{2}\right), \\
\frac{\partial}{\partial x_{2}} \Psi_{2}\left(\lambda ; \gamma_{1}, \gamma_{2} ; x_{1}, x_{2}\right)=\frac{\lambda}{\gamma_{2}} \Psi_{2}\left(\lambda+1 ; \gamma_{1}, \gamma_{2}+1 ; x_{1}, x_{2}\right),
\end{array}\right.
$$

2) higher derivatives;

$$
\left\{\begin{array}{l}
\frac{\partial^{2}}{\partial x_{1} \partial x_{2}} \Psi_{2}\left(\lambda ; \gamma_{1}, \gamma_{2} ; x_{1}, x_{2}\right)=\frac{\lambda(\lambda+1)}{\gamma_{1} \gamma_{2}} \Psi_{2}\left(\lambda+2 ; \gamma_{1}+1, \gamma_{2}+1 ; x_{1}, x_{2}\right), \\
\frac{\partial^{2}}{\partial x_{1}^{2}} \Psi_{2}\left(\lambda ; \gamma_{1}, \gamma_{2} ; x_{1}, x_{2}\right)=\frac{\lambda(\lambda+1)}{\gamma_{1}\left(\gamma_{1}+1\right)} \Psi_{2}\left(\lambda+2 ; \gamma_{1}+2, \gamma_{2} ; x_{1}, x_{2}\right), \\
\frac{\partial^{2}}{\partial x_{2}^{2}} \Psi_{2}\left(\lambda ; \gamma_{1}, \gamma_{2} ; x_{1}, x_{2}\right)=\frac{\lambda(\lambda+1)}{\gamma_{2}\left(\gamma_{2}+1\right)} \Psi_{2}\left(\lambda+2 ; \gamma_{1}, \gamma_{2}+2 ; x_{1}, x_{2}\right), \\
\frac{\partial^{m}}{\partial x_{1}^{m}} \Psi_{2}\left(\lambda ; \gamma_{1}, \gamma_{2} ; x_{1}, x_{2}\right)=\frac{\lambda(\lambda+1) \ldots(\lambda+m-1)}{\gamma_{1}\left(\gamma_{1}+1\right) \ldots\left(\gamma_{1}+m-1\right)} \Psi_{2}\left(\lambda+m ; \gamma_{1}+m, \gamma_{2} ; x_{1}, x_{2}\right), \\
\frac{\partial^{n}}{\partial x_{2}^{n}} \Psi_{2}\left(\lambda ; \gamma_{1}, \gamma_{2} ; x_{1}, x_{2}\right)=\frac{\lambda(\lambda+1) \ldots(\lambda+n-1)}{\gamma_{2}\left(\gamma_{2}+1\right) \ldots\left(\gamma_{2}+n-1\right)} \Psi_{2}\left(\lambda+n ; \gamma_{1}, \gamma_{2}+n ; x_{1}, x_{2}\right), \\
\frac{\partial^{m+n}}{\partial x_{1}^{m} \partial x_{2}^{n}} \Psi_{2}\left(\lambda ; \gamma_{1}, \gamma_{2} ; x_{1}, x_{2}\right)=\frac{\lambda(\lambda+1) \ldots(\lambda+m+n-1)}{\gamma_{1}\left(\gamma_{1}+1\right) \ldots\left(\gamma_{1}+m-1\right) \cdot \gamma_{2}\left(\gamma_{2}+1\right) \ldots\left(\gamma_{2}+n-1\right)} \\
. \Psi_{2}\left(\lambda+m+n ; \gamma_{1}+m, \gamma_{2}+n ; x_{1}, x_{2}\right) .
\end{array} .\right.
$$


Similarly, it is possible to find derivatives of the other particular solutions of (2.15)-(2.17), using the kind of derivatives (2.18), (2.19).

2.2. Differential properties of a function that reduces to the Bessel function of two variables

The degenerate system (2.6) based on theorem 2.1 has four linearly independent partial solutions $\left(2.7_{1}\right)-\left(2.7_{4}\right)$. The first particular solution defines a series that reduces to the Bessel function of two variables

$$
J\left(\gamma_{1} ; x_{1}\right) J\left(\gamma_{2} ; x_{2}\right)=\sum_{m, n=0}^{\infty} \frac{1}{\left(\gamma_{1}\right)_{m}\left(\gamma_{2}\right)_{n}} \cdot \frac{x_{1}^{m}}{m !} \cdot \frac{x_{2}^{n}}{n !},
$$

The derivative (2.20) can be found as products of two functions $J\left(\gamma_{1} ; x_{1}\right)$ and $J\left(\gamma_{2} ; x_{2}\right)$.

Theorem 2.7. Derivatives of functions reduced to the Bessel function of two variables are represented as

$$
\begin{aligned}
1 . \frac{\partial}{\partial x_{1}}\left[J\left(\gamma_{1} ; x_{1}\right) J\left(\gamma_{2} ; x_{2}\right)\right] & =\frac{1}{\gamma_{1}}\left[J\left(\gamma_{1}+1 ; x_{1}\right) J\left(\gamma_{2} ; x_{2}\right)\right], \\
2 \cdot \frac{\partial}{\partial x_{2}}\left[J\left(\gamma_{1} ; x_{1}\right) J\left(\gamma_{2} ; x_{2}\right)\right] & =\frac{1}{\gamma_{2}}\left[J\left(\gamma_{1} ; x_{1}\right) J\left(\gamma_{2}+1 ; x_{2}\right)\right] .
\end{aligned}
$$

Second derivatives:

$$
\begin{aligned}
3 . \frac{\partial^{2}}{\partial x_{1} \partial x_{2}}\left[J\left(\gamma_{1} ; x_{1}\right) J\left(\gamma_{2} ; x_{2}\right)\right] & =\frac{1}{\gamma_{1} \gamma_{2}}\left[J\left(\gamma_{1}+1 ; x_{1}\right) J\left(\gamma_{2}+1 ; x_{2}\right)\right], \\
4 . \frac{\partial^{2}}{\partial x_{1}^{2}}\left[J\left(\gamma_{1} ; x_{1}\right) J\left(\gamma_{2} ; x_{2}\right)\right] & =\frac{1}{\left(\gamma_{1}\right)_{2}}\left[J\left(\gamma_{1}+2 ; x_{1}\right) J\left(\gamma_{2} ; x_{2}\right)\right], \\
5 \cdot \frac{\partial^{2}}{\partial x_{2}^{2}}\left[J\left(\gamma_{1} ; x_{1}\right) J\left(\gamma_{2} ; x_{2}\right)\right] & =\frac{1}{\left(\gamma_{2}\right)_{2}}\left[J\left(\gamma_{1} ; x_{1}\right) J\left(\gamma_{2}+2 ; x_{2}\right)\right] .
\end{aligned}
$$

Higher derivatives:

$$
\begin{gathered}
6 \cdot \frac{\partial^{m_{1}}}{\partial x_{1}^{m_{1}}}\left[J\left(\gamma_{1} ; x_{1}\right) J\left(\gamma_{2} ; x_{2}\right)\right]=\frac{1}{\left(\gamma_{1}\right)_{m_{1}}}\left[J\left(\gamma_{1}+m_{1} ; x_{1}\right) J\left(\gamma_{2} ; x_{2}\right)\right], \\
7 \cdot \frac{\partial^{m_{2}}}{\partial x_{2}^{m_{2}}}\left[J\left(\gamma_{1} ; x_{1}\right) J\left(\gamma_{2} ; x_{2}\right)\right]=\frac{1}{\left(\gamma_{2}\right)_{m_{2}}}\left[J\left(\gamma_{1} ; x_{1}\right) J\left(\gamma_{2}+m_{2} ; x_{2}\right)\right], \\
8 \cdot \frac{\partial^{m_{1}+m_{2}}}{\partial x_{1}^{m_{1}} \partial x_{2}^{m_{2}}}\left[J\left(\gamma_{1} ; x_{1}\right) J\left(\gamma_{2} ; x_{2}\right)\right]=\frac{1}{\left(\gamma_{1}\right)_{m_{1}}\left(\gamma_{2}\right)_{m_{2}}}\left[J\left(\gamma_{1}+m_{1} ; x_{1}\right) J\left(\gamma_{2}+m_{2} ; x_{2}\right)\right] .
\end{gathered}
$$

Similarly are determined by the derivatives of the particular solutions of $\left(2.7_{2}\right)-\left(2.7_{4}\right)$, in particular using (2.21). The main differential properties of the Bessel function of two variables were studied in the works $[10 ; 23]$. The differential properties of degenerate hypergeometric functions of one variable are given in the monographs of Lucy J. Slater [1; 15] and [11-13].

Let's consider the addition property of a degenerate hypergeometric function (2.10):

$$
J\left(\gamma ; x_{1}+x_{2}\right)=\sum_{m, n=0}^{\infty} \frac{1}{(\gamma)_{m+n}} \cdot \frac{x_{1}^{m}}{m !} \cdot \frac{x_{2}^{n}}{n !},
$$

obtained as a particular solution of a degenerate hypergeometric system (2.11).

Theorem 2.8. For the degenerate hypergeometric function (2.11) there is an equality:

$$
J\left(\gamma ; x_{1}+x_{2}\right)=\sum_{n=0}^{\infty} J^{(n)}\left(x_{1}\right) \cdot \frac{x_{2}^{n}}{n !} .
$$


Proof. The formula is used to prove the theorem

$$
f(x+y)=\sum_{n=0}^{\infty} f^{(n)}(x) \cdot \frac{y^{n}}{n !},
$$

applied by Lucy J.Slater $[1 ; 22]$ in establishing the theorem of addition for the derivatives of the Kummer functions of $F_{1}[a ; b ; x]$. So, on the basis of $(2.23)$ we obtain rightly $(2.22)$ :

$$
\begin{gathered}
J\left(\gamma ; x_{1}+x_{2}\right)=\sum_{n=0}^{\infty} J^{(n)}\left(x_{1}\right) \cdot \frac{x_{2}^{n}}{n !}=J^{(0)}\left(\gamma ; x_{1}\right) \frac{x_{2}^{0}}{0 !}+J^{\prime}\left(\gamma+1 ; x_{1}\right) \frac{x_{2}}{1 !}+ \\
+J^{\prime \prime}\left(\gamma+2 ; x_{1}\right) \frac{x_{2}^{2}}{2 !}+\ldots+J^{(n)}\left(\gamma+n ; x_{1}\right)+\ldots=\sum_{n=0}^{\infty} \frac{1}{(\gamma)_{n}} \cdot \frac{x_{2}^{n}}{n !} \cdot J^{(n)}\left(\gamma+n ; x_{1}\right) .
\end{gathered}
$$

Theorem 2.9. For a degenerate hypergeometric function $J\left(\gamma ; x_{1}, x_{2}\right)$, there is equality:

$$
J\left(\gamma ; x_{1} \cdot x_{2}\right)=\sum_{n=0}^{\infty} \frac{x_{1}^{n}\left(x_{2}-1\right)^{n}}{(\gamma)_{n} \cdot n !} \cdot J\left(\gamma+n ; x_{1}\right) .
$$

The formula is used to prove the theorem

$$
f\left(x_{1} \cdot x_{2}\right)=\sum_{n=0}^{\infty} \frac{x_{1}^{n}\left(x_{2}-1\right)^{n}}{n !} \cdot \frac{d^{n}}{d x^{n}}\left\{f\left(x_{1}\right)\right\} .
$$

obtained from (2.23) by substitution $x_{2}$ for $\left(x_{2}-1\right) x_{1}$ and by Taylor's theorem.

Theorem 2.9 is related to the multiplication theorem for Kummer functions [1;23].

3. Construction of normal-regular solutions of Bessel-type system

Problem statement. From the Horn system (1.6) by converting the form,

$$
Z=\exp \left(\frac{x_{1}}{2}+\frac{x_{2}}{2}\right) x_{1}^{-\frac{\gamma_{1}}{2}} \cdot x_{2}^{-\frac{\gamma_{2}}{2}} \cdot U\left(x_{1}, x_{2}\right)
$$

a system of Bessel-type is installed

$$
\left\{\begin{array}{l}
x_{1}^{2} \cdot U_{x_{1} x_{1}}-x_{1} x_{2} \cdot U_{x_{2}}+\left\{-\frac{1}{4} x_{1}^{2}-\frac{1}{2} x_{1} x_{2}+k x_{1}+\alpha(1-\alpha)\right\} U=0, \\
x_{2}^{2} \cdot U_{x_{2} x_{2}}-x_{1} x_{2} \cdot U_{x_{1}}+\left\{-\frac{1}{4} x_{2}^{2}-\frac{1}{2} x_{1} x_{2}+k x_{2}+\beta(1-\beta)\right\} U=0,
\end{array}\right.
$$

where $k=\alpha+\beta-\lambda$ and $\alpha, \beta, \lambda$ are some parameters, and $U=U\left(x_{1}, x_{2}\right)$ is general unknown.

Using the Frobenius-Latysheva method [14] it is required to prove that the solutions of the system (3.2) are functions that reduce to Bessel functions of two variables.

Theorem 3.1. The Bessel-type system (3.2) under the conditions of compatibility and integrability [6] has four linearly independent partial solutions

$$
\left\{\begin{array}{l}
U_{1}\left(x_{1}, x_{2}\right)=\exp \left(-\frac{x_{1}}{2}-\frac{x_{2}}{2}\right) \cdot x_{1}^{\alpha} \cdot x_{2}^{\beta} \cdot \Psi_{2}\left(\lambda, 2 \alpha, 2 \beta ; x_{1}, x_{2}\right), \\
U_{2}\left(x_{1}, x_{2}\right)=\exp \left(-\frac{x_{1}}{2}-\frac{x_{2}}{2}\right) \cdot x_{1}^{\alpha} \cdot x_{2}^{1-\beta} \cdot \Psi_{2}\left(\lambda-2 \beta+1,2 \alpha, 2 \beta-2 ; x_{1}, x_{2}\right), \\
U_{3}\left(x_{1}, x_{2}\right)=\exp \left(-\frac{x_{1}}{2}-\frac{x_{2}}{2}\right) \cdot x_{1}^{1-\alpha} \cdot x_{2}^{\beta} \cdot \Psi_{2}\left(\lambda-2 \alpha+1,2 \alpha-2,2 \beta ; x_{1}, x_{2}\right), \\
U_{4}\left(x_{1}, x_{2}\right)=\exp \left(-\frac{x_{1}}{2}-\frac{x_{2}}{2}\right) \cdot x_{1}^{1-\alpha} \cdot x_{2}^{1-\beta} \cdot \Psi_{2}\left(\lambda-2 \alpha-2 \beta+1,2 \alpha-2,2 \beta-2 ; x_{1}, x_{2}\right),
\end{array}\right.
$$

which are expressed in terms of the degenerate Humbert hypergeometric function reduced when $\gamma_{1}=2 \alpha, \gamma_{2}=2 \beta$ to the Bessel function of two variables by the limit transition

$$
\lim _{\lambda \rightarrow 0} \Psi_{2}\left(\lambda, 2 \alpha, 2 \beta ; \lambda x_{1}, \lambda x_{2}\right)=\sum_{m, n=0}^{\infty} \frac{1}{(2 \alpha)_{m}(2 \beta)_{n}} \cdot \frac{x_{1}^{m}}{m !} \cdot \frac{x_{2}^{n}}{n !} .
$$


The Frobenius-Latysheva method is used to prove the theorem $[14 ; 160]$. The studied system belongs to the Whittaker-type system [5; 132]. The application of the Frobenius-Latysheva method to the construction of a Whittaker-type system solution is described in the works [15; 27]. It was found out that its solutions are normal-regular species,

$$
Z\left(x_{1}, x_{2}\right)=\exp Q\left(x_{1}, x_{2}\right) \cdot x_{1}^{\rho} \cdot x_{2}^{\sigma} \sum_{m, n=0}^{\infty} A_{m, n} \cdot x_{1}^{m} \cdot x_{2}^{n} ;\left(A_{0,0} \neq 0\right),
$$

where $\rho, \sigma, A_{m, n}(m, n=0,1,2, \ldots)$ are unknown constants; $Q=Q\left(x_{1}, x_{2}\right)$ polynomial of two variables:

$$
Q\left(x_{1}, x_{2}\right)=\frac{\alpha_{p 0}}{p} x_{1}^{p}+\frac{\alpha_{0 p}}{p} x_{2}^{p}+\ldots+\alpha_{11} x_{1} x_{2}+\alpha_{10} x_{1}+\alpha_{01} x_{2},
$$

with unknown coefficients $\alpha_{p 0}, \alpha_{0 p}, \ldots, \alpha_{11}, \alpha_{10}, \alpha_{01}$.

In the theory of ordinary differential equations with variable coefficients greater role will be played by the notion of rank $p=1+k$ introduced by H. Poincare, and the concept of antirank $m=-1-\chi$, introduced by L. Tome. Professor of Kiev University K. Ya. Latysheva used these concepts: to determine the polynomial $Q$, as well as in the classification of regular and irregular points of a given equation $[16 ; 50]$.

The studied system (3.2) has a rank $p=1>0$ and antirank $m \leq 0$ [16, p.53]. Therefore, the singularity $(\infty, \infty)$ is irregular, and the singularity $(0,0)$ is regular and there is a normal-regular solution of the form (3.5). The highest degree of the polynomial (3.6) is equal to the rank of the system, that is $p=1$. Then, the polynomial (3.6) turns into a polynomial of the first degree $Q\left(x_{1}, x_{2}\right)=\alpha_{10} x_{1}+\alpha_{01} x_{2}$ and its unknown coefficients $\alpha_{10}$ and $\alpha_{01}$ are determined from the auxiliary system obtained from (3.2) by the transformation in form (3.1):

$$
U=\exp \left(\alpha_{10} x_{1}+\alpha_{01} x_{2}\right) \cdot \Phi\left(x_{1}, x_{2}\right)
$$

where $\Phi\left(x_{1}, x_{2}\right)$ is a new unknown function, by equating to zero coefficients at higher degrees of independent variables $x_{1}$ and $x_{2}$ :

$$
f_{10}^{(1)}\left(\alpha_{10}, \alpha_{01}\right)=\alpha_{10}^{2}-\frac{1}{4}=0, f_{01}^{(2)}\left(\alpha_{10}, \alpha_{01}\right)=\alpha_{01}^{2}-\frac{1}{4}=0 .
$$

The resulting system of characteristic equations (3.8) has four pairs of roots:

$$
\begin{gathered}
\left(\alpha_{10}^{(1)}, \alpha_{01}^{(1)}\right)=\left(\frac{1}{2}, \frac{1}{2}\right),\left(\alpha_{10}^{(1)}, \alpha_{01}^{(2)}\right)=\left(\frac{1}{2},-\frac{1}{2}\right), \\
\left(\alpha_{10}^{(2)}, \alpha_{01}^{(1)}\right)=\left(-\frac{1}{2}, \frac{1}{2}\right),\left(\alpha_{10}^{(2)}, \alpha_{01}^{(2)}\right)=\left(-\frac{1}{2},-\frac{1}{2}\right) .
\end{gathered}
$$

In (3.9) only a pair $\left(\alpha_{10}^{(2)}, \alpha_{01}^{(2)}\right)=\left(-\frac{1}{2},-\frac{1}{2}\right)$ defines a joint system

$$
\left\{\begin{array}{l}
x_{1}^{2} \cdot \Phi_{x_{1} x_{1}}-x_{1}^{2} \cdot \Phi_{x_{1}}-x_{1} x_{2} \cdot \Phi_{x_{2}}+\left[k x_{1}+\alpha(1-\alpha)\right] \Phi=0, \\
x_{2}^{2} \cdot \Phi_{x_{1} x_{1}}-x_{2}^{2} \cdot \Phi_{x_{2}}-x_{1} x_{2} \cdot \Phi_{x_{1}}+\left[k x_{2}+\beta(1-\beta)\right] \Phi=0,
\end{array}\right.
$$

where $k=\alpha+\beta-\lambda$ and $\alpha, \beta, \lambda$ are some parameters, and $\Phi=\Phi\left(x_{1}, x_{2}\right)$ is unknown.

It has four linearly independent partial solutions, which are expressed in terms of the degenerate Humbert hypergeometric function $\Psi_{2}\left(\lambda ; \gamma_{1}, \gamma_{2} ; x_{1}, x_{2}\right),\left(\gamma_{1}=2 \alpha, \gamma_{2}=2 \beta\right)$ :

$$
\left\{\begin{array}{l}
\Phi_{1}\left(x_{1}, x_{2}\right)=x_{1}^{\alpha} \cdot x_{2}^{\beta} \cdot \Psi_{2}\left(\lambda, 2 \alpha, 2 \beta ; x_{1}, x_{2}\right), \\
\Phi_{2}\left(x_{1}, x_{2}\right)=x_{1}^{\alpha} \cdot x_{2}^{1-\beta} \cdot \Psi_{2}\left(\lambda-2 \beta+1,2 \alpha, 2 \beta-2 ; x_{1}, x_{2}\right), \\
\Phi_{3}\left(x_{1}, x_{2}\right)=x_{1}^{1-\alpha} \cdot x_{2}^{\beta} \cdot \Psi_{2}\left(\lambda-2 \alpha+1,2 \alpha-2,2 \beta ; x_{1}, x_{2}\right), \\
\Phi_{4}\left(x_{1}, x_{2}\right)=x_{1}^{1-\alpha} \cdot x_{2}^{1-\beta} \cdot \Psi_{2}\left(\lambda-2 \alpha-2 \beta+1,2 \alpha-2,2 \beta-2 ; x_{1}, x_{2}\right) .
\end{array}\right.
$$


It should be noted that the system of defining equations relating the peculiarity $(0,0)$ :

$$
f_{00}^{(1)}(\rho, \sigma)=\rho(\rho-1)+\alpha(\alpha-1)=0, f_{00}^{(2)}(\rho, \sigma)=\sigma(\sigma-1)+\beta(\beta-1)=0,
$$

has four pairs of roots

$$
\begin{aligned}
\left(\rho_{1}, \sigma_{1}\right)=(\alpha, \beta),\left(\rho_{1}, \sigma_{2}\right) & =(\alpha, 1-\beta), \\
\left(\rho_{2}, \sigma_{1}\right)=(1-\alpha, \beta),\left(\rho_{2}, \sigma_{2}\right) & =(1-\alpha, 1-\beta) .
\end{aligned}
$$

They identified the indicators of the series (3.11). We will draw some conclusions here.

Theorem 3.2. In order to have at least one solution of the form (3.5) for the auxiliary system obtained from the system (3.2) by transformation (3.7), it is necessary and sufficient to perform equality (3.8).

(3.8) has four pairs of roots. This is the first necessary condition for the existence of a normal-regular solution of the form (3.5) associated with the definition of unknown constants $\alpha_{p 0}, \alpha_{0 p}, \ldots, \alpha_{11}, \alpha_{10}, \alpha_{01}$ polynomial $Q\left(x_{1}, x_{2}\right)$.

The second necessary condition is related to the definition of unknown constants $\rho, \sigma, A_{m, n}(m, n=0,1,2, \ldots)$ in $(3.5)$.

Theorem 3.3. To have a solution in the form of a generalized power series of two variables for the system (3.10), it is necessary that the pair $(\rho, \sigma$,$) to be the root of the system of defining equations$ regarding features (3.12) obtained by substituting $\mathrm{b}(3.10)$ instead of the unknown $\Phi\left(x_{1}, x_{2}\right)=x_{1}^{\rho} \cdot x_{2}^{\sigma}$.

The fulfillment of two necessary conditions ensures the existence of four normal-regular solutions of the form (3.3). The theorem is proved.

Summary.

1. Equality (3.4) on the basis of (2.2) and (2.3) when $\gamma_{1}=2 \alpha$ and $\gamma_{2}=2 \beta$ is represented as

$$
\begin{gathered}
J\left(\gamma_{1}, \gamma_{2} ; x_{1}, x_{2}\right)=J\left(2 \alpha, 2 \beta ; x_{1}, x_{2}\right)= \\
=\sum_{m, n=0}^{\infty} \frac{1}{(2 \alpha)_{m}(2 \beta)_{n}} \cdot \frac{x_{1}^{m}}{m !} \cdot \frac{x_{2}^{n}}{n !}=J\left(2 \alpha ; x_{1}\right) J\left(2 \beta ; x_{2}\right),
\end{gathered}
$$

Then, on the basis of (2.5) the Bessel function of two variables of the first kind, we obtain in the form

$$
J_{2 \alpha, 2 \beta}\left(x_{1}, x_{2}\right)=\sum_{m, n=0}^{\infty} \frac{(-1)^{m+n}}{m ! \cdot n ! \Gamma(2 \alpha+m+1) \Gamma(2 \beta+n+1)} \cdot\left(\frac{x_{1}}{2}\right)^{2 m+2 \alpha} \cdot\left(\frac{x_{2}}{2}\right)^{2 n+2 \beta} .
$$

The course of proof as in (2.6).

2. The derivative (3.13) can be found as in 2.2. taking the meanings $\gamma_{1}=2 \alpha, \gamma_{2}=2 \beta$ into account. We give a General formula:

$$
\frac{\partial^{m+n}}{\partial x_{1}^{m} \partial x_{2}^{n}}\left[J\left(2 \alpha ; x_{1}\right) J\left(2 \beta ; x_{2}\right)\right]=\frac{1}{(2 \alpha)_{m}(2 \beta)_{n}}\left[J\left(2 \alpha+m ; x_{1}\right) J\left(2 \beta+n ; x_{2}\right)\right] .
$$

Out of this we can derive various special cases of lower derivatives.

3. The solutions of the attached system (3.10) are expressed in terms of the Humbert hypergeometric function, which is reduced to the Bessel function of two variables by a limit transition (3.4). We have seen that in this case equality is true (3.13). Therefore,

$$
\begin{aligned}
& \lim _{\lambda \rightarrow \infty} \Phi_{j}\left(x_{1}, x_{2}\right)=\lim _{\lambda \rightarrow \infty}\left[x_{1}^{\alpha} \cdot x_{2}^{\beta} \cdot \Psi\left(\lambda, 2 \alpha, 2 \beta ; x_{1}, x_{2}\right)\right]= \\
& =x_{1}^{\alpha} \cdot x^{\beta} \lim _{\lambda \rightarrow \infty} \Psi\left(\lambda, 2 \alpha, 2 \beta ; x_{1}, x_{2}\right)=J\left(2 \alpha, 2 \beta ; x_{1}, x_{2}\right),
\end{aligned}
$$

that is, in this case, in the limiting transition, all $\Phi_{j}\left(x_{1}, x_{2}\right),(j=\overline{1,4})$ are expressed through the function $J\left(2 \alpha, 2 \beta ; x_{1}, x_{2}\right)$. Similarly, all the particular solutions of system (3.2) are also expressed via (3.13). 
Thus, we have established and studied a number of systems with solutions in the form of degenerate hypergeometric Humbert functions of two variables, which reduces to Bessel functions of two variables. The connection between these functions of two variables as solutions of systems of partial differential equations of the second order is revealed. Their properties, as well as differential properties, addition and multiplication theorems, have been investigated so far. Further, these properties make it possible to establish recurrent relations between these functions, as well as between degenerate hypergeometric functions of two and many variables as a whole. A system of Bessel-type has been installed and the features of the application of the method of Frobenius-Latysheva for the construction of normal-regular solutions installed by our system is shown. It is also shown that the Bessel-type system is related to the Whittaker-type system, the features of the solution of which are studied by M.P. Humbert [5; 132].

\section{References}

1 Слейтер Л.Дж. Вырожденные гипергеометрические функции / Л.Дж. Слейтер. - М.: Вычислительный центр, 1966. - 249 с.

2 Бейтмен Г. Высшие трансцендентные функции. - Ч. І. Гипергеометрическая функция. Функции Лежандра / Г. Бейтмен, А. Эрдейи. - М.: Наука, 1965. - 294 с.

3 Бейтмен Г. Высшие трансцендентные функции. - Ч. II. Функции Бесселя, функции параболического цилиндра, ортогональные многочлены / Г. Бейтмен, А. Эрдейи. - М.: Наука, 1974. - 295 c.

4 Tasmambetov Zh.N. Construction of normal-regular decisions of Bessel typed special system / Zh.N. Tasmambetov, M.Zh. Talipova // Abstracts of VI Congress of the Turkic world mathematical Society (October 2-5, 2017). - Astana, Kazakhstan. - P. 138-139.

5 Appell P. Fonctions hypergeometriques et hypesperiques / P. Appell, M.J. Kampe de Feriet. Paris: Gauthier Villars, 1926. - 434p.

6 Wilczynski E.J. Projective differential geometry of Curves and Ruled surfaces / E.J. Wilczynski. - Leipzig: Leubner, 1966. - 120 p.

7 Кампе де Ферье Ж. Функции математической физики / Ж.Кампе де Ферье, Р. Кемпбелл, Г. Петьо, Т. Фогель. - М.: ГИФМЛ, 1963. - 162 с.

8 Тасмамбетов Ж.Н. О свойствах произведения функций Бесселя / Ж.Н.Тасмамбетов // Дифференциальные уравнения и математическая физика: тр. Междунар. науч. конф. - Алматы, 2014. - С. 203-207.

9 Тасмамбетов Ж.Н. Построение вырожденной гипергеометрической функции, сводящейся к функциям Бесселя двух переменных / Ж.Н. Тасмамбетов, Р.У. Жахина, А.Ж. Тасмамбетова // Наука, новые технологии и инновации Кыргызстана. - Бишкек, 2017. - № 7 . C. 85-89.

10 Aktas R. On a two-variable analogue of the Bessel functions / R.Aktas, A.Altin, B.Gekim // Journal of Inequalities and special functions. ISSN: 2217-4303. - Vol. 3. - Issue 4(2012). P. 13-23.

11 Slater L.J. Generalized hypergeometric functions / L.J. Slater. - Cambridge: at the university Press, 1966. - $274 \mathrm{p}$.

12 Кратцер А. Трансцендентные функции / А. Кратцер, В. Франц. - М.: ИЛ, 1963. - 465 с.

13 Кузнецов Д. С. Специальные функции / Д.С. Кузнецов. - М.: Высш. шк., 1965. - 423 с.

14 Тасмамбетов Ж.Н. Построение нормальных и нормально-регулярных решений специальных систем дифференциальных уравнений в частных производных второго порядка / Ж.Н. Тасмамбетов. - Актобе: ИП Жанадилов С.Т., 2015. - 464 с.

15 Тасмамбетов Ж.Н. Об иррегулярных особых кривых систем типа Уиттекера / Ж.Н. Тасмамбетов // Вестн. СамГТУ. Сер. Физ.-мат. науки. - 2013. - № 4(33). - С. 25-33. 
16 Латышева К.Я. Нормально-регулярные решения и их приложения / К.Я. Латышева, Н.И. Терещенко, Г. С.Орёл. - Киев: Вища шк., 1974. - 136 с.

Ж.Н. Тасмамбетов, А.А. Исенова

\title{
Екі айнымалының Бессель функциялары екінші ретті дербес туындылы дифференциалдық теңдеулер жүйесінің шешімі ретінде
}

\begin{abstract}
Мақалада екі айнымалының Бессель функцияларына келтірілетін туындалған гипергеометриялық екі айнымалыларының Гумберт функциялары түріндегі шешімдері мен жүйелері орнатылған және зерттелген. Екі айнымалының Гумберт мен Бессель функциялары араларындағы байланыстар орнатылған олардың дифференциалдық қасиеттері зерттелген. Қосындылау және көбейту теоремалары дәлелденген. Әрі қарай олар бұл қасиеттер алдағы уақытта екі айнымалының туындалған гипергеометриялық функциялары араларында, Бессельдің екі айнымалының функциялары араларында өзара рекурренттік қатынастар орнатуға, әрі аталған қасиеттерді көп айнымалылар жағдайына таратуға мүмкіндік береді. Уиттекер және Бессель жүйелері араларындағы байланыстар көрсетілген. Фробениус-Латышева әдісінің көмегімен жаңадан құрылған Бессель текті жүйенің қалыптырегулярлы шешімдерінің құрылуының ерекшеліктері зерттелген.
\end{abstract}

Kiлm сөздер: Гумберт функциясы, жүйе, Бессель функциясы, қасиеттер, қосу теоремасы, Бессель функциясына келтірілген, қалыпты-регулярлы.

\author{
Ж.Н. Тасмамбетов, А.А. Исенова \\ Функции Бесселя двух переменных как \\ решения систем дифференциальных уравнений \\ в частных производных второго порядка
}

\begin{abstract}
В статье установлены и изучены системы с решениями в виде вырожденных гипергеометрических функций Гумберта двух переменных, сводящиеся к функциям Бесселя двух переменных. Раскрыты связи между функциями Гумберта и Бесселя двух переменных, исследованы их дифференциальные свойства. Доказаны теоремы сложения и умножения. В дальнейшем они позволят установить рекуррентные соотношения между вырожденными гипергеометрическими функциями двух переменных, а также будут способствовать распространению этих свойств на случай многих переменных. Показана связь между системами типа Уиттекера и Бесселя. Методом Фробениуса-Латышевой изучены особенности построения нормально-регулярных решений вновь установленной системы типа Бесселя.
\end{abstract}

Ключевые слова: функция Гумберта, система, функция Бесселя, свойства, теорема сложения, сводящаяся к функциям Бесселя, нормально-регулярное.

\section{References}

1 Sleiter, L.Dz. (1966). Vyrozhdennye hiperheometricheskie funktsii [Degenerated hypergeometric functions]. Moscow: Vychislitelnyi tsentr [in Russian].

2 Beitmen, G. \& Erdeii, A. (1965). Vysshie transtsendentnye funktsii. Chast I. Hiperheometricheskaia funktsiia. Funktsiia Lezhandra /Higher Transcendental Functions.Part I. Hypergeometric functions. The functions of the Lezhanders]. Moscow: Nauka [in Russian]. 
3 Beitmen, G. \& Erdeii, A. (1974). Vysshie transtsendentnye funktsii. Chast II. Funktsii Besselia, funktsii parabolicheskoho tsilindra, ortohonalnye mnohochleny [Higher Transcendental Functions. Part II.Bessel functions, functions of parabolic cylinder, the orthogonal polynoms]. Moscow: Nauka [in Russian].

4 Tasmambetov, Zh.N. \& Talipova, M.Zh.(2017). Construction of normal-regular decisions of Bessel typed special system . Abstracts of VI Congress of the Turkic world mathematical Society. Astana, Kazakhstan.

5 Appell, P. \& Kampe de Feriet, M.J.(1926). Fonctions hypergeometriques et hypesperiques. Paris: Gauthier Villars.

6 Wilczynski, E.J. (1966). Projective differential geometry of Curves and Ruled surfaces. Leipzig: Leubner.

7 Kampe de Feriet, M.J., Kambell, R., Peto,G. \& Fohell, T. (1957). Funktsii matematicheskoi fiziki [Functions of mathematical physics]. Moscow:GIFML [in Russian].

8 Tasmambetov, Zh.N.(2014). O svoistvakh proizvedeniia funktsii Besselia [On the properties of the product of Bessel functions]. Trudy Mezhdunarodnoi nauchnoi konferentsii - Proceedings of the International scientific conference. Almaty [in Russian].

9 Tasmambetov, Zh. N., Zhakhina, R.U. \& Tasmambetova, A.Zh. (2017). Postroenie vyrozhdennoi hiperheometricheskoi funktsii, svodiashcheisia $\mathrm{k}$ funktsiiam Besselia dvukh peremennykh [The Construction of the degenerated hypergeometric function reduces to the Bessel functions of two variables]. Bishkek, 7, 85-89 [in Russian].

10 Aktas, R., Altin, A. \& Gekim, B. (2012). On a two variable analogue of the Bessel functions. Journal of Inequalities and special functions. 3, 4, 13-23.

11 Slater, L.J. (1966). Generalized hypergeometric functions. Cambridge: at the university Press.

12 Krattser, A. \& Frants, V.(1963). Transtsendentnye funktsii [Transcendental functions]. Moscow: IL [in Russian].

13 Kusnetsov, D.S. (1965). Spetsialnye funktsii [Special functions]. Moscow: Vysshaia shkola [in Russian].

14 Tasmambetov, Zh.N.(2015). Postroenie normalnykh i normalno-rehuliarnykh reshenii spetsialnykh sistem differentsialnykh uravnenii $v$ chastnykh proizvodnykh vtoroho poriadka /Construction of normal and normally-regular solutions of special systems of partial equations of second order]. Aktobe: IP Zhanadilov S.T. [in Russian].

15 Tasmambetov, Zh.N.(2013). Ob irrehuliarnykh osobykh krivykh sistem tipa Uittekera [On irregular singular curves of systems of the Whittaker type]. Vestnik SamHTU. Seriia fiziko-matematicheskie nauki, 4(33), 25-33 [in Russian].

16 Latysheva, K.Ya., Tereschenko, N.I. \& Orel, G.S. (1974). Normalno-rehuliarnye resheniia $i$ ikh prilozheniia [Normal regular solutions and their applications]. Kiev: Vishcha shkola [in Russian]. 